\title{
Dosage Parameters in Pediatric Outcome Studies Reported in 9 Peer-Reviewed Occupational Therapy Journals from 2008 to 2014: A Content Analysis
}

\author{
Bryan M. Gee, ${ }^{1}$ Kimberly Lloyd, ${ }^{1}$ Nancy Devine, ${ }^{1}$ Erin Tyrrell, ${ }^{2}$ Trisha Evans, ${ }^{2}$ \\ Rebekah Hill, ${ }^{2}$ Stacee Dineen, ${ }^{2}$ and Kristin Magalogo ${ }^{2}$ \\ ${ }^{1}$ Department of Physical and Occupational Therapy, Idaho State University, Campus Mail Box 8045, Pocatello, ID 83201-8045, USA \\ ${ }^{2}$ Idaho State University, Pocatello, ID 83201-8045, USA
}

Correspondence should be addressed to Bryan M. Gee; geebrya@isu.edu

Received 29 September 2015; Revised 28 December 2015; Accepted 31 December 2015

Academic Editor: Tyng-Guey Wang

Copyright (c) 2016 Bryan M. Gee et al. This is an open access article distributed under the Creative Commons Attribution License, which permits unrestricted use, distribution, and reproduction in any medium, provided the original work is properly cited.

Occupational therapists determine the dosage when establishing the plan of care for their pediatric clients. A content analysis was conducted using 123 pediatric occupational therapy outcomes studies from 9 scholarly international occupational therapy journals. The parameters of dosage were calculated using descriptive statistics in order to obtain a representation of dosage available within the current collage of pediatric occupational therapy outcomes studies. The results revealed that most studies reported portions of dosage parameters within the published studies. The average findings for the subcomponents related to dosage were session length (minutes) $M=58.7$, duration of plan of care (weeks) $M=12.1$, session frequency (per week) $M=3.4$, and total hours of therapy (hours) $M=18.1$. This first attempt at describing and calculating dosage related to pediatric occupational therapy practice indicates that evidence is lacking within the published literature to adequately guide OT dosage decisions. Further research related to dosage in pediatric occupational therapy practice is needed.

\section{Introduction}

Occupational therapists (OTs) determine the intervention dosage when establishing the plan of care for their pediatric clients as a part of the routine occupational therapy process [1]. The dosage selected for the provision of occupational therapy services is likely to influence the overall effectiveness of the intervention provided [2]. Published research literature may provide evidence to guide the choices of OTs when making dosage decisions in order to achieve the best possible outcomes for the most reasonable cost. However, it is not currently known how prevalent published research is that includes data regarding parameters and decision making towards intervention dosage.

Dosage may be defined as the combination of the frequency of treatment sessions, intensity of the intervention provided, duration of the episode of care, and the type of intervention or interventions applied [2-4]. The combination of these parameters of dosage likely interact to produce the outcome achieved. Research addressing different combinations of frequency, intensity, and duration for a particular intervention or combination of interventions would provide valuable evidence to guide the choices of OTs when making dosage decisions in pediatric clinical practice.

There are multiple influences that could impact an OTs choice of dosage when establishing the plan of care for a pediatric client. In addition to the evidence available within the research literature, an OTs choice of dosage could be influenced by client factors (medical diagnosis, age, client/family/care provider goals, etc.) [3], practice setting dynamics (setting type such as school or outpatient, scheduling logistics, colleagues' choices) $[5,6]$ reimbursement (restrictions on the number of visits funded by insurance) [7], and the choice of interventions. Research is needed to identify and better understand the process OTs use to select the dosage for a client's plan of care and which factors influence dosage decisions the most. 
A search of PubMed, Ovid, and CINAHL of the published literature for the previous 15 years revealed only one published article describing decision making of dosage for outcomes following provision of physical therapy and occupational therapy services for adult clients [8]. No literature was found describing the relationship between dosage and therapeutic outcome for physical therapy or occupational therapy interventions for the decision making for pediatric clients. Within the published literature, there is inconsistent reporting of frequency, duration, and intensity of services provided, with an apparent emphasis on the type of intervention used. The lack of evidence to support dosage decisions requires the reader to infer potential influences of different components of dosage, often with incomplete information. Research is needed to fill the gap in the literature regarding the components and parameters of dosage decisions in occupational therapy research and practice and how they influence the provision of service for pediatric populations.

The purpose of this study was to ascertain the dosage parameters included in published outcome studies related to pediatric occupational therapy practice in key occupational therapy journals between the years 2008 and 2014. The guiding research question for this study was the following: How frequently are dosage parameters published in pediatric OT outcome studies? Our hypotheses were as follows: (1) Dosage parameters will be included within published OT outcome studies addressing pediatric interventions and (2) the current literature will include more outcome studies with partial than complete dosage parameters. A focused content analysis of recently published research literature identified the breadth and depth of the evidence available to inform an OTs dosage decisions for pediatric clients. The information provided by this study may indicate how available evidence is for guiding dosage decisions in pediatric OT clinical practice and influence future research on the inclusion and investigation of dosage parameters.

\section{Methods}

2.1. Operational Definitions. For consistency throughout the process of this content analysis, intervention was defined as "to assist the client in reaching a state of physical, mental, and social well-being; to identify and realize aspirations; to satisfy needs; and to change or cope with the environment" (AOTA, p. 652). Pediatric occupational therapy was defined as a scope of occupational therapy practice for children and youth (0-21 years old) who exhibit occupational performance deficits in the areas of work, leisure/play, social participation, activities of daily living/instrumental activities of daily living, and education $[9,10]$. Intervention frequency was defined as the number of treatment sessions (AOTA, 2006) and intervention duration was the length of the intervention plan [11-13]. Intervention intensity referred to the length of each intervention session (i.e., 60 minutes) and the type of service delivery (i.e., $1: 1$ or group) [12,14-17]. Using a format of categorization and analysis exemplified by May-Benson and Koomar, [7] dosage was defined as including aspects related to an intervention's duration (weeks), sessions per week, minutes per session, treatment session length, and total therapy hours. Each category of dosage, if provided, was used as a metric of analysis.

2.2. Inclusion Criteria. For this study published articles that reported quantitative, measurable outcomes for pediatric clients between birth to 21 years of age were included in the initial review. In addition, articles had to report on occupational therapy interventions that fell within the Occupational Therapy Practice Framework: 3rd Edition (OTPF) and targeted pediatric clients, their teachers, caregivers, and/or parents. Furthermore, to be included in the review, articles must have stated at least one or more of the parameters regarding the frequency, intensity, and/or duration of the intervention tested as defined previously. Articles published between 2008 and 2014 in one of the following occupational therapy specific journals were considered for this study (see Table 1).

2.3. Exclusion Criteria. For the purposes of this review, systematic reviews or qualitative studies were not included. In addition, articles published in nonoccupational therapy journals were excluded since they typically do not report their connection to the OTPF which may not focus on the interventions most relevant to occupational therapy. Articles were excluded if they did not report at least one of the parameters of frequency, intensity, or duration of therapy or if they measured nonintervention aspects of the occupational therapy process (i.e., evaluation tools).

2.4. Procedures. A total of 123 outcome studies ultimately were included within the analysis and are listed in the Appendix. Two researchers and five graduate research assistants were assigned to screen the most current seven years (2008-2014) of each occupational therapy journal online via the journal's website. We read the abstract and methods section of each article in each journal reviewed (see Table 1) to determine if the article met all of the inclusion criteria. In the event that access to an article was unavailable through the Idaho State University library or other web-based resources, only the abstract was reviewed to determine if the inclusion and exclusion criteria were likely to be met and an interlibrary loan request was needed.

After all of the targeted journals were screened, the first review of each article was conducted and the following information was recorded: duration (weeks) of services, number of sessions per week, duration of each session (minutes), total therapy hours, type of delivery (1:1 or group), sample size, and level of evidence. A second reviewer analyzed the same information from each article and tracked the number of disagreements. Any disagreements were then discussed by the first and second reviewer. If the first and second reviewers were unable to come to an agreement, the issues were brought to the weekly meetings for all reviewers to discuss and resolve. Conflicts and final decisions were documented for each article.

\section{Results}

One hundred and twenty three articles were found meeting the inclusion criteria. The data gathered from the articles 
TABLE 1: Journal list.

Journal name

American Journal of Occupational Therapy (AJOT)

Canadian Journal of Occupational Therapy (CJOT)

British Journal of Occupational Therapy (BJOT)

Australian Occupational Therapy Journal (AOTJ)

Occupational Therapy Journal of Research (OTJR)

Physical and Occupational Therapy in Pediatrics (POTP)

Occupational Therapy International (OTI)

Journal of Occupational Therapy, Schools, \& Early Intervention (JOTSEI)

Scandinavian Journal of Occupational Therapy (SJOT)

representing sample size and the dosage parameters were analyzed using descriptive statistics (mean, median, and standard deviation) (see Table 2). Overall the American Journal of Occupational Therapy yielded the most pediatric outcomes studies $(n=58)$ with the remaining eight journals containing 14 or fewer during the previous seven years (see Figure 1).

All of the articles that met the inclusion criteria reported the number of participants who participated in each study (see Table 2) and there was a large range of sample sizes represented. The reporting of other subcomponents ranged from 75 to $88 \%$ (percentage equals the total $n$ of articles divided by the $n$ of articles reporting specific dosage subcomponents) of the articles. The length of each treatment session was the most reported subcomponent and the total number of therapy hours received was the least frequently reported (see Table 2).

\section{Discussion}

The purpose of this content analysis of pediatric outcome studies focusing on dosage was to investigate the availability of evidence to guide OTs making decisions for intervention planning with pediatric clients. The results of this study indicate that the majority of published outcome studies in pediatric OT journals that include at least one dosage parameter also include an additional dosage parameter. However, not all of the parameters are available within every article. This finding suggests there is some evidence available to clinically practicing pediatric OTs regarding some of the parameters of dosage needed when developing the plan of care. It also suggests that OTs currently must rely on clinical experience when selecting dosage parameters that are not fully represented within the literature. Further research and more complete documentation of dosage parameters are needed to ensure that the results of outcome studies may be applied clinically in an effective manner.

The results of this study display a wide range of OT practice and research that suggests a high intensity and frequency of intervention over shorter periods of time is used in outcome studies of pediatric occupational therapy interventions. It is not known whether the dosage of these
TABLE 2: Descriptive statistics.

\begin{tabular}{lcccc}
\hline Dosage subcomponents & Mean & Median & $\begin{array}{c}\text { Standard } \\
\text { deviation }\end{array}$ & Range \\
\hline $\begin{array}{l}\text { Sample size }(N=123) \\
\text { Number of participants }\end{array}$ & 32.3 & 37.8 & 12 & $1-200$ \\
\hline $\begin{array}{l}\text { Session length } \\
(n=108 ; 88 \%)\end{array}$ & 58.7 & 45 & 78.8 & $3-270$ \\
$\begin{array}{l}\text { Minutes } \\
\text { Duration of Plan of Care } \\
(n=106 ; 86 \%)\end{array}$ & 12.1 & 10 & 12.5 & $0.14-96$ \\
$\begin{array}{l}\text { In weeks } \\
\begin{array}{l}\text { Session frequency } \\
(n=98 ; 80 \%)\end{array}\end{array}$ & 3.4 & 2 & 3.3 & $1-10$ \\
$\begin{array}{l}\text { Number per week } \\
\begin{array}{l}\text { Total hours of therapy } \\
(n=92 ; 75 \%)\end{array}\end{array}$ & 18.1 & 10 & 20.3 & $0.34-100$ \\
\hline \begin{tabular}{l} 
Hours \\
\hline
\end{tabular} & & & & \\
\hline
\end{tabular}

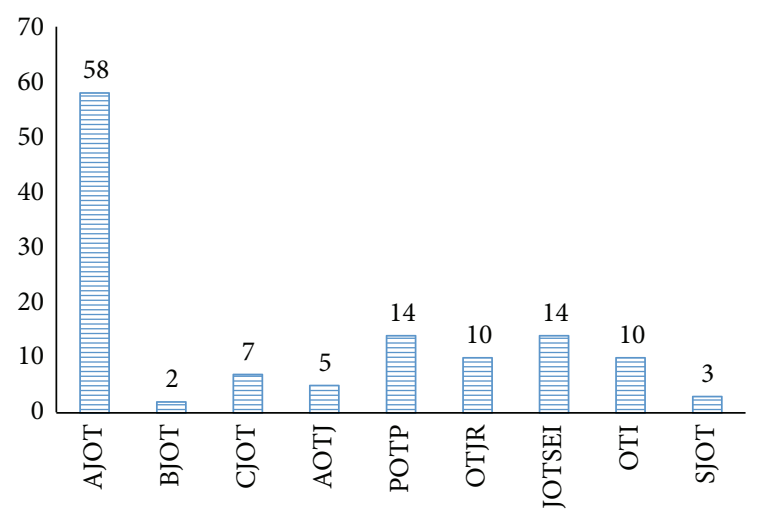

Figure 1: Frequency of articles from the journals reviewed. American Journal of Occupational Therapy: AJOT, British Journal of Occupational Therapy: BJOT, Canadian Journal of Occupational Therapy: CJOT, Scandinavian Journal of Occupational Therapy: SJOT, Physical and Occupational Therapy in Pediatrics: POTP, Occupational Therapy International: OTI, Journal of Occupational Therapy in Schools and Early Intervention: JOTSEI, Journal of Australian Occupational Therapy: AOTJ, and Occupational Therapy Journal of Research: OTJR.

interventions applied in clinical practice is consistent with the dosage used within the outcome studies. Our findings provide a clear depiction of how intervention dosage is represented when the aggregate of a large cluster of outcome studies are compiled for a single client population within one profession.

4.1. Duration. The duration of the plan of care was relatively frequently reported $(86 \%)$ by the articles in this content review. Due to the heterogeneity of studies included in this review, the range of duration is substantial, spanning from 0.14 weeks to 96 weeks. The studies that were at the bottom and top end of the range and standard deviation for the duration of the length of plan of care in this content review 
may be heavily influenced by studies we labeled as "outliers." For example, one study by Bates [18] was a case report of a single child who received outpatient occupational therapy services for almost two years. Ryan et al. [19], on the other end of the reported range, reported a total length of intervention of 1 hour ( 0.14 weeks) provided in a single session. The diversity of the duration of the plan of care reflected in our sample indicates the published literature does not yet provide a clear guideline for this dosage subcomponent.

4.2. Sessions per Week. Of the 98 studies that reported the frequency of sessions per week, 31 studies indicated that their intervention had occurred a single time per week. Conversely, on the other end of the reported range was a study by Lin, Lee, Chang, and Hong (2014) who explored the effectiveness of weighted vests with children diagnosed with $\mathrm{ADHD}$ and impulse control which reported 10 sessions per week of their intervention. The purpose and content of each study may have a strong influence on the number of sessions scheduled each week. The client's diagnosis and specific needs may require multiple, frequent sessions with interventions provided directly by a licensed therapist while other clients may benefit most from receiving less frequent care and having their home exercise plan progressed as appropriate. Clinically practicing pediatric OTs may use the results of this study to compare their own choices for selecting the frequency of sessions. However, the existing literature does not provide a clear guideline for selecting the frequency of sessions when developing the plan of care.

4.3. Minutes per Session. Similar to the length of the plan of care, the study at the top and the bottom of the overall range and size of the standard deviation is due to studies we labeled as "outliers." An example may be found in Pizur-Barnekow et al. [20] who explored visual behavior and vagal reaction during structured activities of object perception with infants in a single intervention session of 4.5 minutes of treatment/session. Conversely, on the other end of the continuum de Brito Brandão et al. [21] explored the effectiveness of constraint therapy and bimanual training in children with cerebral palsy with their intervention lasting a duration of 360 minutes of treatment/day. These findings display the complexity inherent in making dosage decisions in OT pediatric practice and strongly support the need for further research to identify how the selection of the number of minutes per OT session is influenced by client factors such as age and diagnosis as well as the choice of intervention.

4.4. Total Therapy Hours. Similar to the length of the session, the studies with the longest and the shortest session length and size of the standard deviation we labeled as "outliers." For example, Classen et al. [22] explored driver simulation for adolescents with ADHD and ASD that lasted a total of 20 minute or 0.33 of an hour. Conversely on the other end of the continuum Nwora and Gee [23] explored the effectiveness of a sound based intervention for children with PDD-NOS lasting a duration of $30 \mathrm{~min} / \mathrm{session}$ and totaled approximately 1800 hours.
TABLE 3: Levels of evidence.

\begin{tabular}{lc}
\hline Level of evidence & $n$ \\
\hline Level I: randomized control trials & 14 \\
Level II: cohort study, controlled trials not randomized & 27 \\
Level III: case-control study & 26 \\
Level IV: case-series, single-subject design & 51 \\
Level V: case report & 6 \\
\hline
\end{tabular}

4.5. Type of Delivery. All 123 of the articles reviewed reported the type of intervention delivery (group, individual, or both) used. Sixty-two of the studies reported using an individual mode of therapeutic delivery, 49 used group-based intervention delivery, and four outcome studies used both types of delivery.

Our analysis also included a comparison of the types of research and the level of evidence sourced in Portney and Watkins [24] (see Table 3, levels of evidence). The most common type of research design found within our review was Level IV (case series, single case) $(n=51)$ and the less frequently found was Level I (randomized control trials).

4.6. Current Discussions of Dosage. Novak [25] stated that the core goal of evidenced based practice was for the therapist to "do the right things for the right client at the right time" (p. 1) in order to optimize therapeutic outcomes. Over the past several years the topic of therapeutic dosage has been brought up within the pediatric rehabilitation literature. A paucity of content related to dosage recommendations continues to plague pediatric practitioners. That being said, recent authors have attempted to address the topic of dosage through opinion pieces, the development of clinical pathways based upon medical/behavioral condition, or tiered decision scaffolds based upon the client's response to a given intervention. Palisono and Murr [26] argued for an approach where dosage was designed around the client's therapy readiness, skill level, and response to the intervention. Gannotti et al. [3] developed a clinical pathway as a method of approaching dosage (sessions per week, duration of session, and the type of specific motor/biomechanical intervention) for children with cerebral palsy (CP). The clinical pathway developed through targeting motor based interventions for children with CP is also uniquely infused with the core constructs of the International Classification System [27]. Bailes et al. [28] developed a clinical scaffold to serve as a guide for clinicians providing services which then informs them on some aspects of dosage (frequency) related to the client's response to therapy. The two clinical guides proposed by Gannotti et al. [3] and Bailes et al. [28] have yet to be explored further by way of clinician and client perspectives or intervention efficiency (greater outcomes in a shorter amount of time). Therefore, dosage is a current topic within the literature that warrants further research.

4.7. Implications for Clinical Practice. Our findings provide an opportunity for pediatric OTs to compare their current dosage decisions but do not provide the premise for demonstrating the most effective dosage parameters to select. In 
TABle 4: Articles reviewed.

\begin{tabular}{|c|c|c|c|}
\hline Author(s) & Year & Article title & Journal \\
\hline $\begin{array}{l}\text { Bundy, Luckett, Naughton, Tranter, } \\
\text { Wyver, Ragen, Singleton, and Spies }\end{array}$ & 2008 & $\begin{array}{l}\text { "Playful Interaction: Occupational } \\
\text { Therapy for All Children on the School } \\
\text { Playground" }\end{array}$ & $\begin{array}{l}\text { American Journal of Occupational } \\
\text { Therapy }\end{array}$ \\
\hline Cope, Forst, Bibis, and Liu & 2008 & $\begin{array}{l}\text { "Modified Constraint-Induced } \\
\text { Movement Therapy for a 12-Month-Old } \\
\text { Child With Hemiplegia: A Case Report" }\end{array}$ & $\begin{array}{l}\text { American Journal of Occupational } \\
\text { Therapy }\end{array}$ \\
\hline Drysdale, Casey, and Porter-Armstrong & 2008 & $\begin{array}{l}\text { "Effectiveness of Training on the } \\
\text { Community Skills of Children with } \\
\text { Intellectual Disabilities" }\end{array}$ & $\begin{array}{l}\text { Scandinavian Journal of Occupational } \\
\text { Therapy }\end{array}$ \\
\hline Lam, Wong, Fulks, and Holsti & 2008 & "Obsessional Slowness: A Case Study" & $\begin{array}{l}\text { Canadian Journal of Occupational } \\
\text { Therapy }\end{array}$ \\
\hline $\begin{array}{l}\text { Di Rezze, Wright, Curran, Campbell, and } \\
\text { Macarthur }\end{array}$ & 2008 & $\begin{array}{l}\text { "Individualized Outcome Measures for } \\
\text { Evaluating Life Skill Groups for Children } \\
\text { with Disabilities" }\end{array}$ & $\begin{array}{l}\text { Canadian Journal of Occupational } \\
\text { Therapy }\end{array}$ \\
\hline Schultz-Kroh, Boener, Dinh, and Phelan & 2008 & $\begin{array}{l}\text { "Handwriting Without Tears-A } \\
\text { Short-Term Intervention for Children } \\
\text { Living in a Homeless Shelter" }\end{array}$ & $\begin{array}{l}\text { Journal of Occupational Therapy in } \\
\text { Schools and Early Intervention }\end{array}$ \\
\hline Lopez and Swinth & 2008 & $\begin{array}{l}\text { "A Group Proprioceptive Program's Effect } \\
\text { on Physical Aggression in Children" }\end{array}$ & $\begin{array}{l}\text { Journal of Occupational Therapy in } \\
\text { Schools and Early Intervention }\end{array}$ \\
\hline $\begin{array}{l}\text { Klein, Erickson, James, Perrott, } \\
\text { Williamson, and Zacharuk }\end{array}$ & 2008 & $\begin{array}{l}\text { "Effectiveness of a Computer Skills } \\
\text { Program to Improve Written } \\
\text { Communication in Children with } \\
\text { Developmental Coordination Disorder" }\end{array}$ & $\begin{array}{l}\text { Physical \& Occupational Therapy in } \\
\text { Pediatrics }\end{array}$ \\
\hline $\begin{array}{l}\text { Barnes, Vogel, Beck, Schoenfeld, and } \\
\text { Owen }\end{array}$ & 2008 & $\begin{array}{l}\text { "Self-Regulation Strategies of Children } \\
\text { with Emotional Disturbance" }\end{array}$ & $\begin{array}{l}\text { Physical \& Occupational Therapy in } \\
\text { Pediatrics }\end{array}$ \\
\hline Eckman, Williams, Riegel, and Paul & 2008 & $\begin{array}{l}\text { "Teaching Chewing: A Structured } \\
\text { Approach" }\end{array}$ & $\begin{array}{l}\text { American Journal of Occupational } \\
\text { Therapy }\end{array}$ \\
\hline Martin, Burtner, Poole, and Phillips & 2008 & $\begin{array}{l}\text { "Case Report: ICF-Level Changes in a } \\
\text { Preschooler After Constraint-Induced } \\
\text { Movement Therapy" }\end{array}$ & $\begin{array}{l}\text { American Journal of Occupational } \\
\text { Therapy }\end{array}$ \\
\hline Munguba, Valdes, and Bruno Da Silva & 2008 & $\begin{array}{l}\text { "The Application of an Occupational } \\
\text { Therapy Nutrition Education Programme } \\
\text { for Children who are Obese" }\end{array}$ & Occupational Therapy International \\
\hline Banks, Rodger, and Polatojko & 2008 & $\begin{array}{l}\text { "Cognitive Orientation to (Daily) } \\
\text { Occupational Performance: Changes in } \\
\text { Strategy and Session Time Use Over the } \\
\text { Course of Intervention" }\end{array}$ & $\begin{array}{l}\text { Occupational Therapy Journal of } \\
\text { Rehabilitation }\end{array}$ \\
\hline Kang, Yoo, Chung, Jung, Chang, and Jeon & 2008 & $\begin{array}{l}\text { "The Application of Client-Centered } \\
\text { Occupational Therapy for Korean } \\
\text { Children with Developmental } \\
\text { Disabilities" }\end{array}$ & Occupational Therapy International \\
\hline Pfeiffer, Henry, Miller, and Witherell & 2008 & $\begin{array}{l}\text { "Effectiveness of Disc 'O' Sit Cushions on } \\
\text { Attention to Task in Second-Grade } \\
\text { Students With Attention Difficulties" }\end{array}$ & $\begin{array}{l}\text { American Journal of Occupational } \\
\text { Therapy }\end{array}$ \\
\hline $\begin{array}{l}\text { Bazyk, Michaud, Goodman, Papp, } \\
\text { Hawkins, and Welch }\end{array}$ & 2009 & $\begin{array}{l}\text { "Integrating Occupational Therapy } \\
\text { Services in a Kindergarten Curriculum: A } \\
\text { Look at the Outcomes" }\end{array}$ & $\begin{array}{l}\text { American Journal of Occupational } \\
\text { Therapy }\end{array}$ \\
\hline Nwora and Gee & 2009 & $\begin{array}{l}\text { "A Case Study of a Five-Year-Old Child } \\
\text { with Pervasive Developmental } \\
\text { Disorder-Not-Otherwise Specified Using } \\
\text { Sound-Based Interventions" }\end{array}$ & Occupational Therapy International \\
\hline Qvarfordt, Engerstrom, and Eliasson & 2009 & $\begin{array}{l}\text { "Guided Eating or Feeding: Three Girls } \\
\text { with Rett Syndrome" }\end{array}$ & $\begin{array}{l}\text { Scandinavian Journal of Occupational } \\
\text { Therapy }\end{array}$ \\
\hline Zwicker and Hadwin & 2009 & $\begin{array}{l}\text { "Cognitive Versus Multisensory } \\
\text { Approaches to Handwriting Intervention: } \\
\text { A Randomized Controlled Trial" }\end{array}$ & $\begin{array}{l}\text { Occupational Therapy Journal of } \\
\text { Rehabilitation }\end{array}$ \\
\hline
\end{tabular}


TABLE 4: Continued.

\begin{tabular}{|c|c|c|c|}
\hline Author(s) & Year & Article title & Journal \\
\hline Weintraub, Yinon, Hirsch, and Parush & 2009 & $\begin{array}{l}\text { "Effectiveness of Sensorimotor and } \\
\text { Task-Oriented Handwriting Intervention } \\
\text { in Elementary School-Aged Students with } \\
\text { Handwriting Difficulties" }\end{array}$ & $\begin{array}{l}\text { Occupational Therapy Journal of } \\
\text { Rehabilitation }\end{array}$ \\
\hline Wuang, Wang, Huang, and Su & 2009 & $\begin{array}{l}\text { "Prospective Study of the Effect of } \\
\text { Sensory Integration, } \\
\text { Neurodevelopmental Treatment, and } \\
\text { Perceptual-Motor Therapy on the } \\
\text { Sensorimotor Performance in Children } \\
\text { With Mild Mental Retardation" }\end{array}$ & $\begin{array}{l}\text { American Journal of Occupational } \\
\text { Therapy }\end{array}$ \\
\hline Roger, Pham, and Mitchell & 2009 & $\begin{array}{l}\text { "Cognitive Strategy Use by Children with } \\
\text { Asperger's Syndrome during Intervention } \\
\text { for Motor-Based Goals" }\end{array}$ & Australian Occupational Therapy Journal \\
\hline Rodger and Brandenburg & 2009 & $\begin{array}{l}\text { "Cognitive Orientation to (Daily) } \\
\text { Occupational Performance (CO-OP) } \\
\text { with Children with Asperger's Syndrome } \\
\text { Who Have Motor-Based Occupational } \\
\text { Performance Goals" }\end{array}$ & Australian Occupational Therapy Journal \\
\hline Lee, Muccio, and Osborne & 2009 & $\begin{array}{l}\text { "The Effect of Chaining Techniques on } \\
\text { Dressing Skills of Children with } \\
\text { Moderate Mental Retardation: A } \\
\text { Single-Subject Design Study" }\end{array}$ & $\begin{array}{l}\text { Journal of Occupational Therapy in } \\
\text { Schools and Early Intervention }\end{array}$ \\
\hline Phelan, Steinke, and Mandich & 2009 & $\begin{array}{l}\text { "Exploring a Cognitive Intervention for } \\
\text { Children with Pervasive Developmental } \\
\text { Disorder" }\end{array}$ & $\begin{array}{l}\text { Canadian Journal of Occupational } \\
\text { Therapy }\end{array}$ \\
\hline Pizur-Barnekow, Kraemer, and Winters & 2009 & $\begin{array}{l}\text { "Pilot Study Investigating Infant Vagal } \\
\text { Reactivity and Visual Behavior During } \\
\text { Object Perception" }\end{array}$ & $\begin{array}{l}\text { American Journal of Occupational } \\
\text { Therapy }\end{array}$ \\
\hline Shimel, Candler, and Neville-Smith & 2009 & $\begin{array}{l}\text { "Comparison of Cursive Handwriting } \\
\text { Instruction Programs among Students } \\
\text { without Identified Problems" }\end{array}$ & $\begin{array}{l}\text { Physical \& Occupational Therapy in } \\
\text { Pediatrics }\end{array}$ \\
\hline $\begin{array}{l}\text { Silva, Ayres, Schalock, Bunse, and } \\
\text { Budden }\end{array}$ & 2009 & $\begin{array}{l}\text { "Qigong Massage Treatment for Sensory } \\
\text { and Self-Regulation Problems in Young } \\
\text { Children With Autism: A Randomized } \\
\text { Controlled Trial" }\end{array}$ & $\begin{array}{l}\text { American Journal of Occupational } \\
\text { Therapy }\end{array}$ \\
\hline $\begin{array}{l}\text { Vaz, Daniela Virginia; Mancini, Marisa } \\
\text { Cotta; do Amaral, Maira Ferreira; de } \\
\text { Brito Brandao, Marina; de Franca } \\
\text { Drummond, Adriana; and da Fonseca, } \\
\text { Sergio Teixeira }\end{array}$ & 2010 & $\begin{array}{l}\text { "Clinical Changes During an Intervention } \\
\text { Based on Constraint-Induced Movement } \\
\text { Therapy Principles on use of the Affected } \\
\text { Arm of a Child with Obstetric Brachial } \\
\text { Plexus Injury: A Case Report" }\end{array}$ & Occupational Therapy International \\
\hline $\begin{array}{l}\text { Gutman, Raphael, Ceder, Khan, Timp, } \\
\text { and Salvant }\end{array}$ & 2010 & $\begin{array}{l}\text { "The Effect of a Motor-Based, Social Skills } \\
\text { Intervention for Adolescents with } \\
\text { High-Functioning Autism: Two } \\
\text { Single-Subject Design Cases" }\end{array}$ & Occupational Therapy International \\
\hline Leew, Stein, and Gibbard & 2010 & $\begin{array}{l}\text { "Weighted Vests' Effect on Social } \\
\text { Attention for Toddlers with Autism } \\
\text { Spectrum Disorders" }\end{array}$ & $\begin{array}{l}\text { Canadian Journal of Occupational } \\
\text { Therapy }\end{array}$ \\
\hline Moir & 2010 & $\begin{array}{l}\text { "Evaluating the Effectiveness of Different } \\
\text { Environments on the Learning of } \\
\text { Switching Skills in Children with Severe } \\
\text { and Profound Multiple Disabilities" }\end{array}$ & British Journal of Occupational Therapy \\
\hline Salem and Gropack & 2010 & $\begin{array}{l}\text { "Aquatic Therapy for a Child with Type } \\
\text { III Spinal Muscular Atrophy: A Case } \\
\text { Report" }\end{array}$ & $\begin{array}{l}\text { Physical \& Occupational Therapy in } \\
\text { Pediatrics }\end{array}$ \\
\hline $\begin{array}{l}\text { Missiuna, DeMatteo, Hanna, Mandich, } \\
\text { Law, Mahoney, and Scott }\end{array}$ & 2010 & $\begin{array}{l}\text { "Exploring the Use of Cognitive } \\
\text { Intervention for Children with Acquired } \\
\text { Brain Injury" }\end{array}$ & $\begin{array}{l}\text { Physical \& Occupational Therapy in } \\
\text { Pediatrics }\end{array}$ \\
\hline
\end{tabular}


TABle 4: Continued.

\begin{tabular}{|c|c|c|c|}
\hline Author(s) & Year & Article title & Journal \\
\hline Shurtleff and Engsberg & 2010 & $\begin{array}{l}\text { "Changes in Trunk and Head Stability in } \\
\text { Children with Cerebral Palsy after } \\
\text { Hippotherapy: A Pilot Study" }\end{array}$ & $\begin{array}{l}\text { Physical \& Occupational Therapy in } \\
\text { Pediatrics }\end{array}$ \\
\hline MaKay, McCluskey, and Mayes & 2010 & $\begin{array}{l}\text { "The Log Handwriting Program in } \\
\text { Improved Children's Writing Legibility" }\end{array}$ & $\begin{array}{l}\text { American Journal of Occupational } \\
\text { Therapy }\end{array}$ \\
\hline Watson, Ito, Smith, and Andersen & 2010 & $\begin{array}{l}\text { "Effect of Assistive Technology in a } \\
\text { Public School Setting" }\end{array}$ & $\begin{array}{l}\text { American Journal of Occupational } \\
\text { Therapy }\end{array}$ \\
\hline Costigan and Light & 2010 & $\begin{array}{l}\text { "Effect of Seated Position on Upper } \\
\text { Extremity Access to Augmentative } \\
\text { Communication for Children with CP" }\end{array}$ & $\begin{array}{l}\text { American Journal of Occupational } \\
\text { Therapy }\end{array}$ \\
\hline Roberts, Siever, and Mair & 2010 & $\begin{array}{l}\text { "Effects of Kinesthetic Cursive } \\
\text { Handwriting Intervention for Grade 4-6 } \\
\text { Students" }\end{array}$ & $\begin{array}{l}\text { American Journal of Occupational } \\
\text { Therapy }\end{array}$ \\
\hline Ryan, Rigby, and Campbell & 2010 & $\begin{array}{l}\text { "Randomized Controlled Trial } \\
\text { Comparing Two School Furniture } \\
\text { Configurations in the Printing } \\
\text { Performance of Young Children with } \\
\text { Cerebral Palsy" }\end{array}$ & Australian Occupational Therapy Journal \\
\hline Hwang, Lin, Coster, Bigsby, and Vergara & 2010 & $\begin{array}{l}\text { "Effectiveness of Check and Jaw Support } \\
\text { to Improve Feeding Performance of } \\
\text { Preterm Infants" }\end{array}$ & $\begin{array}{l}\text { American Journal of Occupational } \\
\text { Therapy }\end{array}$ \\
\hline $\begin{array}{l}\text { Bagatell, Mirigliani, Patterson, Reyes, and } \\
\text { Test }\end{array}$ & 2010 & $\begin{array}{l}\text { "Effectiveness of Therapy Ball Chairs on } \\
\text { Classroom Participation in Children with } \\
\text { ASD" }\end{array}$ & $\begin{array}{l}\text { American Journal of Occupational } \\
\text { Therapy }\end{array}$ \\
\hline Chard and Pierse & 2011 & $\begin{array}{l}\text { "The Effect of Introducing Non-Play } \\
\text { Items into a Primary School Playground } \\
\text { in Ireland" }\end{array}$ & $\begin{array}{l}\text { Journal of Occupational Therapy in } \\
\text { Schools and Early Intervention }\end{array}$ \\
\hline $\begin{array}{l}\text { Wilkes, Cordier, Bundy, Docking, and } \\
\text { Munro }\end{array}$ & 2011 & $\begin{array}{l}\text { "A Play-based Intervention for Children } \\
\text { with ADHD: A Pilot Study" }\end{array}$ & Australian Occupational Therapy Journal \\
\hline Meyer, Rice, and Metz & 2011 & $\begin{array}{l}\text { "Knowledge of Results and Learning to } \\
\text { Tell Time with Typically Developing 7- } \\
\text { and 8-Year-Old Children: A Single } \\
\text { Subject Research Design" }\end{array}$ & $\begin{array}{l}\text { Journal of Occupational Therapy in } \\
\text { Schools and Early Intervention }\end{array}$ \\
\hline Benson, Beeman, Smitsky, and Provident & 2011 & $\begin{array}{l}\text { "The Deep Pressure and Proprioceptive } \\
\text { Technique (DPPT) versus Nonspecific } \\
\text { Child-Guided Brushing: A Case Study" }\end{array}$ & $\begin{array}{l}\text { Journal of Occupational Therapy in } \\
\text { Schools and Early Intervention }\end{array}$ \\
\hline Dunford & 2011 & $\begin{array}{l}\text { "Goal-Oriented Group Intervention for } \\
\text { Children with Developmental } \\
\text { Coordination Disorder" }\end{array}$ & $\begin{array}{l}\text { Physical \& Occupational Therapy in } \\
\text { Pediatrics }\end{array}$ \\
\hline Dionne and Martini & 2011 & $\begin{array}{l}\text { "Floor Time Play with a Child with } \\
\text { Autism: A Single-Subject Study" }\end{array}$ & $\begin{array}{l}\text { Canadian Journal of Occupational } \\
\text { Therapy }\end{array}$ \\
\hline Bates & 2011 & $\begin{array}{l}\text { "Congenital Diaphragmatic Hernia and } \\
\text { Occupational Therapy: A Case Report" }\end{array}$ & $\begin{array}{l}\text { Physical \& Occupational Therapy in } \\
\text { Pediatrics }\end{array}$ \\
\hline $\begin{array}{l}\text { Pfeiffer, Koeing, Kinnealey, Sheppard, } \\
\text { and Henderson }\end{array}$ & 2011 & $\begin{array}{l}\text { "Effectiveness of Sensory Integration } \\
\text { Interventions in Children with Autism } \\
\text { Spectrum Disorders: A Pilot Study" }\end{array}$ & $\begin{array}{l}\text { American Journal of Occupational } \\
\text { Therapy }\end{array}$ \\
\hline Rowe, Candler, and Neville & 2011 & $\begin{array}{l}\text { "Noise Reduction Headphones and } \\
\text { Autism: A Single Case Study" }\end{array}$ & $\begin{array}{l}\text { Journal of Occupational Therapy in } \\
\text { Schools and Early Intervention }\end{array}$ \\
\hline Taras, Brennan, Gilbert, and Reed & 2011 & $\begin{array}{l}\text { "Effectiveness of Occupational Therapy } \\
\text { Strategies for Teaching Handwriting } \\
\text { Skills to Kindergarten Children" }\end{array}$ & $\begin{array}{l}\text { Journal of Occupational Therapy in } \\
\text { Schools and Early Intervention }\end{array}$ \\
\hline Umeda and Deitz & 2011 & $\begin{array}{l}\text { "Effects of Therapy Cushions on } \\
\text { Classroom Behaviors of Children with } \\
\text { Autism Spectrum Disorder" }\end{array}$ & $\begin{array}{l}\text { American Journal of Occupational } \\
\text { Therapy }\end{array}$ \\
\hline
\end{tabular}


TABLE 4: Continued.

\begin{tabular}{|c|c|c|c|}
\hline Author(s) & Year & Article title & Journal \\
\hline Hahn-Markowitz, Manor, and Maeir & 2011 & $\begin{array}{l}\text { "Effectiveness of Cognitive-Functional } \\
\text { (Cog-Fun) Intervention with Children } \\
\text { With Attention Deficit Hyperactivity } \\
\text { Disorder: A Pilot Study" }\end{array}$ & $\begin{array}{l}\text { American Journal of Occupational } \\
\text { Therapy }\end{array}$ \\
\hline Fedewa and Erwin & 2011 & $\begin{array}{l}\text { "Stability Balls and Students with } \\
\text { Attention and Hyperactivity Concerns: } \\
\text { Implications for On Task and In Seat } \\
\text { behaviors" }\end{array}$ & $\begin{array}{l}\text { American Journal of Occupational } \\
\text { Therapy }\end{array}$ \\
\hline Golos, Sarid, Weill, and Weintraub & 2011 & $\begin{array}{l}\text { "Efficacy of an Early Intervention } \\
\text { Program for At Risk Preschool Boys: A } \\
\text { Two-Group Control Study" }\end{array}$ & $\begin{array}{l}\text { American Journal of Occupational } \\
\text { Therapy }\end{array}$ \\
\hline Lust and Donica & 2011 & $\begin{array}{l}\text { "Effectiveness of a Handwriting } \\
\text { Readiness Program in Head Start: A } \\
\text { Two-Group Controlled Trial" }\end{array}$ & $\begin{array}{l}\text { American Journal of Occupational } \\
\text { Therapy }\end{array}$ \\
\hline Silva, Schalock, and Gabrielson & 2011 & $\begin{array}{l}\text { "Early Intervention for Autism with a } \\
\text { Parent-Delivered Qigong Massage } \\
\text { Program: A Randomized Controlled } \\
\text { Trial" }\end{array}$ & $\begin{array}{l}\text { American Journal of Occupational } \\
\text { Therapy }\end{array}$ \\
\hline Stagnitti O’Connor and Sheppard & 2012 & $\begin{array}{l}\text { "Impact of the Learn to Play Program on } \\
\text { Play, Social Competence, and Language } \\
\text { for Children Aged 5-8 Years Who Attend } \\
\text { a Specialist School" }\end{array}$ & Australian Occupational Therapy Journal \\
\hline $\begin{array}{l}\text { Sawatzky, Rushton, Denison, and } \\
\text { McDonald }\end{array}$ & 2012 & $\begin{array}{l}\text { "Wheelchair Skills Training Programme } \\
\text { for Children: A Pilot Study" }\end{array}$ & Australian Occupational Therapy Journal \\
\hline Shurtleff and Engsberg & 2012 & $\begin{array}{l}\text { "Long-Term Effects of Hippotherapy on } \\
\text { One Child with Cerebral Palsy: A } \\
\text { Research Case Study" }\end{array}$ & British Journal of Occupational Therapy \\
\hline Schneck, Shasby, Meyers, and DePoy & 2012 & $\begin{array}{l}\text { "Handwriting without Tears versus } \\
\text { Teacher-Designed Handwriting } \\
\text { Instruction in First Grade Classrooms" }\end{array}$ & $\begin{array}{l}\text { Journal of Occupational Therapy, } \\
\text { Schools, \& Early Intervention }\end{array}$ \\
\hline Lawson, Cox, and Blackwell & 2012 & $\begin{array}{l}\text { "Yoga as a Classroom Intervention for } \\
\text { Preschoolers" }\end{array}$ & $\begin{array}{l}\text { Journal of Occupational Therapy, } \\
\text { Schools, \& Early Intervention }\end{array}$ \\
\hline $\begin{array}{l}\text { Reidy, Naber, Viguers, Allison, Brady, } \\
\text { Carney, Salorio, and Pidock }\end{array}$ & 2012 & $\begin{array}{l}\text { "Outcomes of a Clinic-Based Pediatric } \\
\text { Constraint-Induced Movement Therapy } \\
\text { Program" }\end{array}$ & $\begin{array}{l}\text { Physical \& Occupational Therapy in } \\
\text { Pediatrics }\end{array}$ \\
\hline $\begin{array}{l}\text { Aarts, Pauline B.; Hartingsveldt, Margo; } \\
\text { Anderson, Patricia G.; Tillaar, Ingrid; } \\
\text { Burg, Jan; and Geurts, Alexander }\end{array}$ & 2012 & $\begin{array}{l}\text { "The Pirate Group Intervention Protocol: } \\
\text { Description and a Case Report of a } \\
\text { Modified Constraint-Induced Movement } \\
\text { Therapy Combined with Bimanual } \\
\text { Training for Young Children with } \\
\text { Unilateral Spastic Cerebral Palsy" }\end{array}$ & Occupational Therapy International \\
\hline Brandão, Gordon, \& Mancini & 2012 & $\begin{array}{l}\text { "Functional Impact of Constraint } \\
\text { Therapy and Bimanual Training in } \\
\text { Children with Cerebral Palsy: A } \\
\text { Randomized Controlled Trial" }\end{array}$ & $\begin{array}{l}\text { American Journal of Occupational } \\
\text { Therapy }\end{array}$ \\
\hline Palsbo and Hood-Szivek & 2012 & $\begin{array}{l}\text { "Effect of Robotic-Assisted } \\
\text { Three-Dimensional Repetitive Motion to } \\
\text { Improve Hand Motor Function and } \\
\text { Control in Children with Handwriting } \\
\text { Deficits: A Nonrandomized Phase } 2 \\
\text { Device Trial" }\end{array}$ & $\begin{array}{l}\text { American Journal of Occupational } \\
\text { Therapy }\end{array}$ \\
\hline Case-Smith, Holland, Lane, and White & 2012 & $\begin{array}{l}\text { "Effect of a Coaching Handwriting } \\
\text { Program for First Graders: One-Group } \\
\text { Pretest-Posttest Design" }\end{array}$ & $\begin{array}{l}\text { American Journal of Occupational } \\
\text { Therapy }\end{array}$ \\
\hline
\end{tabular}


TABLe 4: Continued.

\begin{tabular}{|c|c|c|c|}
\hline Author(s) & Year & Article title & Journal \\
\hline $\begin{array}{l}\text { Dunn, Cox, Foster, Mische-Lawson, and } \\
\text { Tanquary }\end{array}$ & 2012 & $\begin{array}{l}\text { "Impact of a Contextual Intervention on } \\
\text { Child Participation and Parent } \\
\text { Competence among Children with } \\
\text { Autism Spectrum Disorders: A } \\
\text { Pretest-Posttest Repeated-Measures } \\
\text { Design" }\end{array}$ & $\begin{array}{l}\text { American Journal of Occupational } \\
\text { Therapy }\end{array}$ \\
\hline Gutman, Raphael, and Rao & 2012 & $\begin{array}{l}\text { "Effect of a Motor Based Role Play } \\
\text { Intervention on the Social Behaviors of } \\
\text { Adolescents with High Functioning ASD: } \\
\text { Multiple Baseline Single Subject Design" }\end{array}$ & $\begin{array}{l}\text { American Journal of Occupational } \\
\text { Therapy }\end{array}$ \\
\hline Koenig, Buckley-Reen, and Garg & 2012 & $\begin{array}{l}\text { "Efficacy of the Get Ready to Learn Yoga } \\
\text { Program among Children with ASD: A } \\
\text { Pretest-Posttest Control Group Design" }\end{array}$ & $\begin{array}{l}\text { American Journal of Occupational } \\
\text { Therapy }\end{array}$ \\
\hline Schaaf, Hunt, and Benevides & 2012 & $\begin{array}{l}\text { "Occupational Therapy Using SI to } \\
\text { Improve Participation of a Child with } \\
\text { ASD: A Case Report" }\end{array}$ & $\begin{array}{l}\text { American Journal of Occupational } \\
\text { Therapy }\end{array}$ \\
\hline $\begin{array}{l}\text { Kinnealey, Pfeiffer, Miller, Roan, Shoener, } \\
\text { and Ellner }\end{array}$ & 2012 & $\begin{array}{l}\text { "Effect of Classroom Modification on } \\
\text { Attention and Engagement of Students } \\
\text { with Autism or Dyspraxia" }\end{array}$ & $\begin{array}{l}\text { American Journal of Occupational } \\
\text { Therapy }\end{array}$ \\
\hline $\begin{array}{l}\text { Silva, Schalock, Garberg, and } \\
\text { Lammers-Smith }\end{array}$ & 2012 & $\begin{array}{l}\text { "Qigong Massage for Motor Skills in } \\
\text { Young Children with Cerebral Palsy and } \\
\text { Down Syndrome" }\end{array}$ & $\begin{array}{l}\text { American Journal of Occupational } \\
\text { Therapy }\end{array}$ \\
\hline Ajzenman, Standeven, and Shurtleff & 2013 & $\begin{array}{l}\text { "Effect of Hippotherapy on Motor } \\
\text { Control, Adaptive Behaviors, and } \\
\text { Participation in Children with Autism } \\
\text { Spectrum Disorder: A Pilot Study" }\end{array}$ & $\begin{array}{l}\text { American Journal of Occupational } \\
\text { Therapy }\end{array}$ \\
\hline Howe, Roston, Sheu, and Hinojosa & 2013 & $\begin{array}{l}\text { "Assessing Handwriting Intervention } \\
\text { Effectiveness in Elementary School } \\
\text { Students: A Two-Group Controlled } \\
\text { Study" }\end{array}$ & $\begin{array}{l}\text { American Journal of Occupational } \\
\text { Therapy }\end{array}$ \\
\hline Bellows, Davies, Anderson, and Kennedy & 2013 & $\begin{array}{l}\text { "Effectiveness of a Physical Activity } \\
\text { Intervention for Head Start Preschoolers: } \\
\text { A Randomized Intervention Study" }\end{array}$ & $\begin{array}{l}\text { American Journal of Occupational } \\
\text { Therapy }\end{array}$ \\
\hline Rowe, Yuen, and Dure & 2013 & $\begin{array}{l}\text { "Comprehensive Behavioral Intervention } \\
\text { to Improve Occupational Performance in } \\
\text { Children with Tourette Disorder" }\end{array}$ & $\begin{array}{l}\text { American Journal of Occupational } \\
\text { Therapy }\end{array}$ \\
\hline Wu, Hung, Tseng, and Huang & 2013 & $\begin{array}{l}\text { "Group Constraint-Induced Movement } \\
\text { Therapy for Children with Hemiplegic } \\
\text { Cerebral Palsy: A Pilot Study" }\end{array}$ & $\begin{array}{l}\text { American Journal of Occupational } \\
\text { Therapy }\end{array}$ \\
\hline Tsai, Meng, Wu, Jang, and Su & 2013 & $\begin{array}{l}\text { "Effects of Visual Rehabilitation on a } \\
\text { Child with Severe Visual Impairment" }\end{array}$ & $\begin{array}{l}\text { American Journal of Occupational } \\
\text { Therapy }\end{array}$ \\
\hline $\begin{array}{l}\text { Ohl, Graze, Weber, Kenny, Salvatore, and } \\
\text { Wagreich }\end{array}$ & 2013 & $\begin{array}{l}\text { "Effectiveness of a 10-Week Tier-1 } \\
\text { Response to Intervention Program in } \\
\text { Improving Fine Motor and Visual-Motor } \\
\text { Skills in General Education Kindergarten } \\
\text { Students" }\end{array}$ & $\begin{array}{l}\text { American Journal of Occupational } \\
\text { Therapy }\end{array}$ \\
\hline $\begin{array}{l}\text { Tokolahi, Em-Chhour, Barkwill, and } \\
\text { Stanley }\end{array}$ & 2013 & $\begin{array}{l}\text { "An Occupation-Based Group for } \\
\text { Children with Anxiety" }\end{array}$ & British Journal of Occupational Therapy \\
\hline Monahan, Classen, and Helsel & 2013 & $\begin{array}{l}\text { "Pre-driving Evaluation of a Teen with } \\
\text { Attention Deficit Hyperactivity Disorder } \\
\text { and Autism Spectrum Disorder" }\end{array}$ & $\begin{array}{l}\text { Canadian Journal of Occupational } \\
\text { Therapy }\end{array}$ \\
\hline
\end{tabular}


TABle 4: Continued.

\begin{tabular}{|c|c|c|c|}
\hline Author(s) & Year & Article title & Journal \\
\hline Olsen, Ross, Foreman, and Engsberg & 2013 & $\begin{array}{l}\text { "Changes in Muscle Activation following } \\
\text { Ankle Strength Training in Children with } \\
\text { Spastic Cerebral Palsy: An } \\
\text { Electromyography Feasibility Case } \\
\text { Report" }\end{array}$ & $\begin{array}{l}\text { Physical and Occupational Therapy in } \\
\text { Pediatrics }\end{array}$ \\
\hline Qualls, Arnold, McEwen, and Jefferies & 2013 & $\begin{array}{l}\text { "Exercise Using the Wii Fit Plus with a } \\
\text { Child with Primary Raynaud's Disease } \\
\text { and Obesity: A Case Report" }\end{array}$ & $\begin{array}{l}\text { Physical and Occupational Therapy in } \\
\text { Pediatrics }\end{array}$ \\
\hline Thompson and Johnston & 2013 & $\begin{array}{l}\text { "Use of Social Stories to Improve } \\
\text { Self-Regulation in Children with Autism } \\
\text { Spectrum Disorders" }\end{array}$ & $\begin{array}{l}\text { Physical and Occupational Therapy in } \\
\text { Pediatrics }\end{array}$ \\
\hline Kurz, Stuberg, DeJong, and Arpin & 2013 & $\begin{array}{l}\text { "Overground Body-Weight-Supported } \\
\text { Gait Training for Children and Youth } \\
\text { with Neuromuscular Impairments" }\end{array}$ & $\begin{array}{l}\text { Physical and Occupational Therapy in } \\
\text { Pediatrics }\end{array}$ \\
\hline $\begin{array}{l}\text { Potasz, Varela De Varela, Coin De } \\
\text { Carvalho, Fernandes Do Prado, and } \\
\text { Fernades Do Prado }\end{array}$ & 2013 & $\begin{array}{l}\text { "Effect of Play Activities on Hospitalized } \\
\text { Children's Stress: A Randomized Clinical } \\
\text { Trial" }\end{array}$ & $\begin{array}{l}\text { Scandinavian Journal of Occupational } \\
\text { Therapy }\end{array}$ \\
\hline Lee, Grey, Ora, Stren, and Sytner & 2013 & $\begin{array}{l}\text { "The Effect of Computer-Based } \\
\text { Intervention on Enhancing Visual } \\
\text { Perception of Preschool Children with } \\
\text { Autism: A Single-Subject Design Study" }\end{array}$ & $\begin{array}{l}\text { Journal of Occupational Therapy in } \\
\text { Schools and Early Intervention }\end{array}$ \\
\hline Kaiser & 2013 & $\begin{array}{l}\text { "Children with Developmental } \\
\text { Coordination Disorder: The Effects of } \\
\text { Combined Intervention on Motor } \\
\text { Coordination, Occupational } \\
\text { Performance, and Quality of Life" }\end{array}$ & $\begin{array}{l}\text { Journal of Occupational Therapy in } \\
\text { Schools and Early Intervention }\end{array}$ \\
\hline Donica, Golns, and Wagner & 2013 & $\begin{array}{l}\text { "Effectiveness of Handwriting Readiness } \\
\text { Programs on Postural Control, Hand } \\
\text { Control, and Letter and Number } \\
\text { Formation in Head Start Classrooms" }\end{array}$ & $\begin{array}{l}\text { Journal of Occupational Therapy in } \\
\text { Schools and Early Intervention }\end{array}$ \\
\hline Sheppard, Osmond, and Stagnitti & 2013 & $\begin{array}{l}\text { "The Effectiveness of a Multidisciplinary } \\
\text { Intervention to Improve School } \\
\text { Readiness in Children with } \\
\text { Developmental Concerns: Children's Skill } \\
\text { Development and Parent Perspective" }\end{array}$ & $\begin{array}{l}\text { Journal of Occupational Therapy in } \\
\text { Schools and Early Intervention }\end{array}$ \\
\hline Bhopti and Brown & 2013 & $\begin{array}{l}\text { "Examining the Wilbargers' Deep } \\
\text { Pressure and Proprioceptive Technique } \\
\text { for Treating Children with Sensory } \\
\text { Defensiveness Using a } \\
\text { Multiple-Single-Case Study" }\end{array}$ & $\begin{array}{l}\text { Journal of Occupational Therapy in } \\
\text { Schools and Early Intervention }\end{array}$ \\
\hline $\begin{array}{l}\text { Garg, Buckley-Reen, Alexander, } \\
\text { Chintakrindi, Venice, and Koeng }\end{array}$ & 2013 & $\begin{array}{l}\text { "The Effectiveness of Manualized Yoga } \\
\text { Intervention on Classroom Behaviors in } \\
\text { Elementary School Children with } \\
\text { Disabilities: A Pilot Study" }\end{array}$ & $\begin{array}{l}\text { Journal of Occupational Therapy in } \\
\text { Schools and Early Intervention }\end{array}$ \\
\hline $\begin{array}{l}\text { Delegato, McLaughline, Derby, and } \\
\text { Schuster }\end{array}$ & 2013 & $\begin{array}{l}\text { "The Effects of Using Handwriting } \\
\text { without Tears and a Handwriting } \\
\text { Racetrack to Teach Five Preschool } \\
\text { Students with Disabilities Pre } \\
\text { Handwriting and Handwriting" }\end{array}$ & $\begin{array}{l}\text { Journal of Occupational Therapy in } \\
\text { Schools and Early Intervention }\end{array}$ \\
\hline $\begin{array}{l}\text { Kennedy-Behr, Rodger, Graham, and } \\
\text { Mickan }\end{array}$ & 2013 & $\begin{array}{l}\text { "Creating Enabling Environments at } \\
\text { Preschool for Children with } \\
\text { Developmental Coordination Disorder" }\end{array}$ & $\begin{array}{l}\text { Journal of Occupational Therapy in } \\
\text { Schools and Early Intervention }\end{array}$ \\
\hline $\begin{array}{l}\text { Hilton, Cumpata, Klohr, Gaetke, Artner, } \\
\text { Johnson, and Dobbs }\end{array}$ & 2014 & $\begin{array}{l}\text { "Effects of Exergaming on Executive } \\
\text { Function and Motor Skills in Children } \\
\text { with Autism Spectrum Disorder: A Pilot } \\
\text { Study" }\end{array}$ & $\begin{array}{l}\text { American Journal of Occupational } \\
\text { Therapy }\end{array}$ \\
\hline
\end{tabular}


TABLE 4: Continued.

Author(s)
Wilkes-Gilen, Bundy, Cordier, and

Lincoln

Smith, Weaver, and Holland

2014

Orban, Erlandsson, Edberg, Onnerfalt, and Thorngren-Jerneck

Maeir, Fisher, Bar-Llan, Boas, Berger, and Landau

"Effect of an Occupation-Focused Family

2014 Intervention on Change in Parents' Time

Intervention for Young Children with Attention Deficit Hyperactivity Disorder:

Lin, Lee, Chang, and Hong

2014

"Test of Ideational Praxis (TIP):

Lane, Ivey, and May-Bensen

2014 Preliminary Findings and Interrater and

Roberts, Derkach-Ferguson, Siever, and Rose

2014 "An Examination of the Effectiveness of Handwriting Without Tears Instruction"

"Effectiveness of a Co-Taught

Case-Smith, Holland, and White

2014 Handwriting Program for First Grade Students"

Pollock, Sharma, Christenson, Law, Gorter, and Darrah

2014 Receiving a Context-Focused

McConnel, Johnston, and Kerr

2014 Therapy for Children Aged 9-11 Years

Lowes, Mayhan, Orr, Batterson, Tonneman, Meyer, and Case-Smith

2014 Constraint-Induced Movement Therapy

"Predicting Handwriting Performance in

Clark and Luze

2014 Kindergarteners Using Reading,

Cobb, Fitzgerald, Lanigan-O-Keeffe, Irwin, and Mellerick

2014 Behavioral Difficulties: The Alert

Iwanaga, Honda, Nakane, Tanaka, Toeda, and Tanaka

2014

Integration Therapy for Japanese

Gee, Thompson, and St. John

2014 Use and Children's Body Mass Index"

"Effectiveness of Cognitive-Functional (Cog-Fun) Occupational Therapy A Controlled Study"

"Effects of Weighted Vests on Attention,

Impulse Control, and On-Task Behavior

in Children with Attention Deficit

Hyperactivity Disorder" Test-Retest Reliability with Preschoolers"

"Change in Parent-Identified Goals in Young Children with Cerebral Palsy Intervention: Associations with Child, Goal and Intervention Factors"

"Efficacy and Acceptability of Reduced Intensity Constraint-Induced Movement with Hemiplegic Cerebral Palsy: A Pilot Study"

"Pilot Study of the Efficacy of for Infants and Toddlers with Cerebral Palsy" Fine-Motor, and Visual-Motor Measures"

"Students with Social, Emotional, and Program Trial in Post-Primary Schools"

"Pilot Study: Efficacy of Sensory

Children with High-Functioning Autism Spectrum Disorder"

"Efficacy of a Sound-Based Intervention

Journal

American Journal of Occupational

Therapy

American Journal of Occupational

Therapy

American Journal of Occupational

Therapy

American Journal of Occupational

Therapy

American Journal of Occupational Therapy

American Journal of Occupational

Therapy

Canadian Journal of Occupational Therapy

Physical and Occupational Therapy in Pediatrics

Physical and Occupational Therapy in Pediatrics

Physical and Occupational Therapy in Pediatrics

Physical and Occupational Therapy in Pediatrics

Journal of Occupational Therapy in Schools and Early Intervention

Journal of Occupational Therapy in Schools and Early Intervention

Occupational Therapy International with a Child with an Autism Spectrum Disorder and Auditory Sensory Over-Responsivity" 
TABLE 4: Continued.

\begin{tabular}{|c|c|c|c|}
\hline Author(s) & Year & Article title & Journal \\
\hline An & 2014 & $\begin{array}{l}\text { "Occupation-Based Family-Centered } \\
\text { Therapy Approach for Young Children } \\
\text { with Feeding Problems in South Korea; A } \\
\text { Case Study" }\end{array}$ & Occupational Therapy International \\
\hline Janeslatt, Kottorp, and Granlund & 2014 & $\begin{array}{l}\text { "Evaluating Intervention Using Time } \\
\text { Aids in Children with Disabilities" }\end{array}$ & $\begin{array}{l}\text { Scandinavian Journal of Occupational } \\
\text { Therapy }\end{array}$ \\
\hline $\begin{array}{l}\text { Almomani, Josman, Al-Momani, } \\
\text { Malkawi, Nazzal, Almahdawi, and } \\
\text { Almomani }\end{array}$ & 2014 & $\begin{array}{l}\text { "Factors Related to Cognitive Function } \\
\text { among Elementary School Children" }\end{array}$ & $\begin{array}{l}\text { Scandinavian Journal of Occupational } \\
\text { Therapy }\end{array}$ \\
\hline Liao, Hwang, Chen, Lee, Chen, and Lin & 2014 & $\begin{array}{l}\text { "Home-Based DIR/Floortime }{ }^{\mathrm{mm}} \\
\text { Intervention Program for Preschool } \\
\text { Children with Autism Spectrum } \\
\text { Disorders: Preliminary Findings" }\end{array}$ & $\begin{array}{l}\text { Physical and Occupational Therapy in } \\
\text { Pediatrics }\end{array}$ \\
\hline $\begin{array}{l}\text { Hape, Flood, McArthur, Sidara, Stephens, } \\
\text { and Welsch }\end{array}$ & 2014 & $\begin{array}{l}\text { "A Pilot Study of the Effectiveness of the } \\
\text { Handwriting without Tears }{ }^{\otimes} \text { Curriculum } \\
\text { in First Grade" }\end{array}$ & $\begin{array}{l}\text { Journal of Occupational Therapy in } \\
\text { Schools and Early Intervention }\end{array}$ \\
\hline $\begin{array}{l}\text { Blackwell, Yeager, Lawson, Bird, and } \\
\text { Cook }\end{array}$ & 2014 & $\begin{array}{l}\text { "Teaching Children Self-Regulation Skills } \\
\text { within the Early Childhood Education } \\
\text { Environment: A Feasibility Study" }\end{array}$ & $\begin{array}{l}\text { Journal of Occupational Therapy in } \\
\text { Schools and Early Intervention }\end{array}$ \\
\hline Candler, Mulder, and Nall & 2014 & $\begin{array}{l}\text { "Embedding Video-Based Modeling } \\
\text { Handwriting Instruction in a Montessori } \\
\text { Preschool Phonics Program" }\end{array}$ & $\begin{array}{l}\text { Journal of Occupational Therapy in } \\
\text { Schools and Early Intervention }\end{array}$ \\
\hline Stewart and Umeda & 2014 & $\begin{array}{l}\text { "Video Modeling in Occupational } \\
\text { Therapy for Very Young Children with } \\
\text { Autism Spectrum Disorder: A Pilot } \\
\text { Study" }\end{array}$ & $\begin{array}{l}\text { Journal of Occupational Therapy in } \\
\text { Schools and Early Intervention }\end{array}$ \\
\hline Chen, Lin, Kang, Wu, Chen, and Hsieh & 2014 & $\begin{array}{l}\text { "Potential Predictors of Functional } \\
\text { Outcomes after Home-Based } \\
\text { Constraint-Induced Therapy for Children } \\
\text { with Cerebral Palsy" }\end{array}$ & $\begin{array}{l}\text { American Journal of Occupational } \\
\text { Therapy }\end{array}$ \\
\hline
\end{tabular}

order for occupational therapy practitioners to incorporate evidence-based practice, to be adherent to the AOTA Code of Ethics (AOTA, 2010) and the 2017 American Occupational Therapy Association's Centennial Vision (Clark, 2010) [29, 30], a better understanding of current dosage decisions by OTs for pediatric interventions is needed. Exploring how dosage is being implemented in clinical research may assist the occupational therapy profession to establish evidence for the prescription of services as related to frequency, intensity, and duration to ensure efficacy. Evidence-based practice should not only include information and evidence regarding valid interventions and assessments but should also include the importance of intensity, frequency, and duration when establishing plans of care for pediatric clients. With healthcare evolving, new policies, and the Affordable Care Act [31], it is going to be increasingly important for OTs to provide guidelines of treatment frequency, intensity, and duration to ensure continuation of insurance coverage for occupational therapy services, in addition to demonstrating the effectiveness and value of occupational therapy services.

The findings of this study reflect the existing foundation of outcomes studies available regarding dosage and can foster reflection among occupational therapy practitioners. Such self-reflection may include guiding questions such as "what is the rationale for duration of the treatment, the number of sessions per week, and the number of minutes per session? Is what I have prescribed supported by the best possible evidence?"

Occupational therapy practitioners would benefit from paying closer attention to the parameters of dosage when exploring and implementing the evidence. They should consider the specific parameters of dosage (frequency, intensity, and duration), rationale for the dosage, and the setting of the intervention delivery within each article supporting their clinical practices.

4.8. Implications for Researcher. After reviewing 123 outcomes studies within occupational therapy specific journals there are several recommendations that researchers should consider as they disseminate findings related to occupational therapy based intervention outcomes applicable to pediatric populations or settings. Researchers should be explicit regarding the dosage parameters related to the intervention being assessed or independent variables measured. Further, it would be helpful if researchers include comments regarding the selection of dosage which may include how funding/reimbursement, time/resources, and/or setting may have been influencing factors. A clear description of how the study's methodology, dosage, and findings should or should not be interpreted and implemented in various practice 
settings is also needed. In addition to connecting the applicability of the findings to clinical practice, researchers should be explicit in the application of their study's methodology, dosage, and findings to better support replication.

4.9. Limitations. The limitations of this study include a heterogeneous sample, specifically diversity among intervention types, sample sizes, conditions/populations, and the journal's focus and specific aims. In addition, the literature search revealed some extreme outliers in all categories of the intervention dosage as noted in previous sections. Lastly, we are aware that the selection of the journals reviewed may result in a content bias since there may be relevant articles published in other sources that were not included within this study.

4.10. Recommendations for Future Research. Areas of future research should include analyzing the published research by adding categories related to setting (0-3 or early intervention, school-based, inpatient hospital and outpatient rehabilitation, and community based) and the type of research (case study or clinical). Analyzing unpublished theses and dissertations as they may include outcomes studies where the intervention did not result in significant findings and exploring their dosage may be advantageous to researchers and clinicians. Investigating outcomes studies back through 2002 may allow for the analysis to include changes in reporting of dosage and actual changes in dosage over time. Finally, evaluating pediatric outcomes studies that generated significant positive findings would be of value. In addition future research should include reviewing journals that are condition specific in an effort to establish the most effective interventions in addition to expanding the knowledge base in regard to the provision of occupational therapy services including dosage of such services. Categorizing and evaluating the funding source as a part of the outcome study (e.g., pro bono, public/private health insurance, government funded insurance, and grant funding) may also be beneficial. Including specific client factors such as severity of the physical, developmental or mental diagnosis, or occupational performance deficit would assist in the dosage discussion. Finally, the pediatric rehabilitation professions (occupational and physical therapy and speech language pathology) need to start exploring the possible links between dosage of an intervention and outcomes on an intervention by intervention and/or condition by condition basis.

\section{Appendix}

See Table 4.

\section{Conflict of Interests}

The authors declare that there is no conflict of interests regarding the publication of this paper.

\section{References}

[1] American Occupational Therapy Association, "Occupational therapy practice framework: domain and process (3rd edition),"
The American Journal of Occupational Therapy, vol. 68, pp. S1S48, 2014.

[2] T. H. A. Kolobe, J. B. Christy, M. E. Gannotti et al., "Research summit III proceedings on dosing in children with an injured brain or cerebral palsy: executive summary," Physical Therapy, vol. 94, no. 7, pp. 907-920, 2014.

[3] M. E. Gannotti, J. B. Christy, J. C. Heathcock, and T. H. A. Kolobe, "A path model for evaluating dosing parameters for children with cerebral palsy," Physical Therapy, vol. 94, no. 3, pp. 411-421, 2014.

[4] L. S. Pescatello, R. Arena, D. Riebe, and P. D. Thompson, Eds., ACSM's Guidelines for Exercise Testing and Prescription, Wolters Kluwer Health/Lippincott Williams \& Wilkins, Philadelphia, $\mathrm{Pa}, \mathrm{USA}, 2014$.

[5] K. S. Hayward, R. N. Barker, A. H. Wiseman, and S. G. Brauer, "Dose and content of training provided to stroke survivors with severe upper limb disability undertaking inpatient rehabilitation: an observational study," Brain Impairment, vol. 14, no. 3, pp. 392-405, 2013.

[6] K. J. Waddell, R. L. Birkenmeier, J. L. Moore, T. G. Hornby, and C. E. Lang, "Feasibility of high-repetition, task-specific training for individuals with upper-extremity paresis," American Journal of Occupational Therapy, vol. 68, no. 4, pp. 444-453, 2014.

[7] T. A. May-Benson and J. A. Koomar, "Systematic review of the research evidence examining the effectiveness of interventions using a sensory integrative approach for children," The American Journal of Occupational Therapy, vol. 64, no. 3, pp. 403-414, 2010.

[8] N. J. Kirk-Sanchez and K. E. Roach, "Relationship between duration of therapy services in a comprehensive rehabilitation program and mobility at discharge in patients with orthopedic problems," Physical Therapy, vol. 81, no. 3, pp. 888-895, 2001.

[9] J. Case-Smith and J. O'Brien, Occupational Therapy for Children, Mosby, St. Louis, Mo, USA, 6th edition, 2010.

[10] S. Lane and A. Bundy, Kids Can be Kids: A Childhood Occupations Approach, F.A. Davis Company, Philadelphia, Pa, USA, 2012.

[11] D. L. Hart, S. Tepper, and D. Lieberman, "Changes in health status for persons with wrist or hand impairments receiving occupational therapy or physical therapy," American Journal of Occupational Therapy, vol. 55, no. 1, pp. 68-74, 2001.

[12] G. Kwakkel, "Impact of intensity of practice after stroke: issues for consideration," Disability and Rehabilitation, vol. 28, no. 1314, pp. 823-830, 2006.

[13] N. K. Latham, D. U. Jette, W. Coster et al., "Occupational therapy activities and intervention techniques for clients with stroke in six rehabilitation hospitals," The American Journal of Occupational Therapy, vol. 60, no. 4, pp. 369-378, 2006.

[14] R. J. Palisano and S. Murr, "Intensity of therapy services: what are the considerations?" Physical and Occupational Therapy in Pediatrics, vol. 29, no. 2, pp. 107-112, 2009.

[15] K. P. Feder, M. B. Racine, and A. Majnemer, "A review of handwriting performance and interventions: does remediation work," Israeli Journal of Occupational Therapy, vol. 17, no. 3, pp. 69-88, 2008

[16] S. F. Warren, M. E. Fey, and P. J. Yoder, "Differential treatment intensity research: a missing link to creating optimally effective communication interventions," Mental Retardation and Developmental Disabilities Research Reviews, vol. 13, no. 1, pp. 70-77, 2007. 
[17] M. K. Kaminker, L. A. Chiarello, M. E. O’Neil, and C. G. Dichter, "Decision making for physical therapy service delivery in schools: aa nationwide survey of pediatric physical therapists," Physical Therapy, vol. 84, no. 10, pp. 919-933, 2004.

[18] A. C. Bates, "Congenital diaphragmatic hernia and occupational therapy: a case report," Physical and Occupational Therapy in Pediatrics, vol. 31, no. 2, pp. 184-197, 2011.

[19] S. E. Ryan, P. J. Rigby, and K. A. Campbell, "Randomised controlled trial comparing two school furniture configurations in the printing performance of young children with cerebral palsy," Australian Occupational Therapy Journal, vol. 57, no. 4, pp. 239-245, 2010.

[20] K. Pizur-Barnekow, G. W. Kraemer, and J. M. Winters, "Pilot study investigating infant vagal reactivity and visual behavior during object perception," The American Journal of Occupational Therapy, vol. 62, no. 2, pp. 198-205, 2008.

[21] M. de Brito Brandão, A. M. Gordon, and M. C. Mancini, "Functional impact of constraint therapy and bimanual training in children with cerebral palsy: a randomized controlled trial," The American Journal of Occupational Therapy, vol. 66, no. 6, pp. 672-681, 2012.

[22] S. Classen, M. Monahan, and Y. Wang, "Driving characteristics of teens with attention deficit hyperactivity and autism spectrum disorder," American Journal of Occupational Therapy, vol. 67, no. 6, pp. 664-673, 2013.

[23] A. J. Nwora and B. M. Gee, "A case study of a five-year-old child with pervasive developmental disorder-not otherwise specified using sound-based interventions," Occupational Therapy International, vol. 16, no. 1, pp. 25-43, 2009.

[24] L. G. Portney and M. P. Watkins, Foundations of Clinical Research: Applications to Practice, Pearson Prentice Hall, Upper Saddle River, NJ, 3rd edition, 2008.

[25] I. Novak, "Evidence to practice commentary: is more therapy better?" Physical and Occupational Therapy in Pediatrics, vol. 32, no. 4, pp. 383-387, 2012.

[26] R. J. Palisano and S. Murr, "Intensity of therapy services: what are the onsiderations," Physical and Occupational Therapy in Pediatrics, vol. 29, no. 2, pp. 107-112, 2009.

[27] World Health Organization, The World Health Report 2002: Reducing Risks, Promoting Healthy Life, World Health Organization, 2002.

[28] A. F. Bailes, R. Reder, and C. Burch, "Development of guidelines for determining frequency of therapy services in a pediatric medical setting," Pediatric Physical Therapy, vol. 20, no. 2, pp. 194-198, 2008.

[29] F. Clark, "High-definition occupational therapy: HD OT," The American Journal of Occupational Therapy, vol. 64, no. 6, pp. 848-854, 2010.

[30] American Occupational Therapy Association, "Occupational therapy code of ethics (2015)," American Journal of Occupational Therapy, vol. 69, supplement 3, 2015.

[31] Patient Protection and Affordable Care Act, Pub. L. 111-148, x 3502, 124 Stat. 119, 124, 2010. 


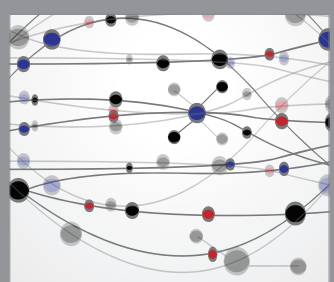

The Scientific World Journal
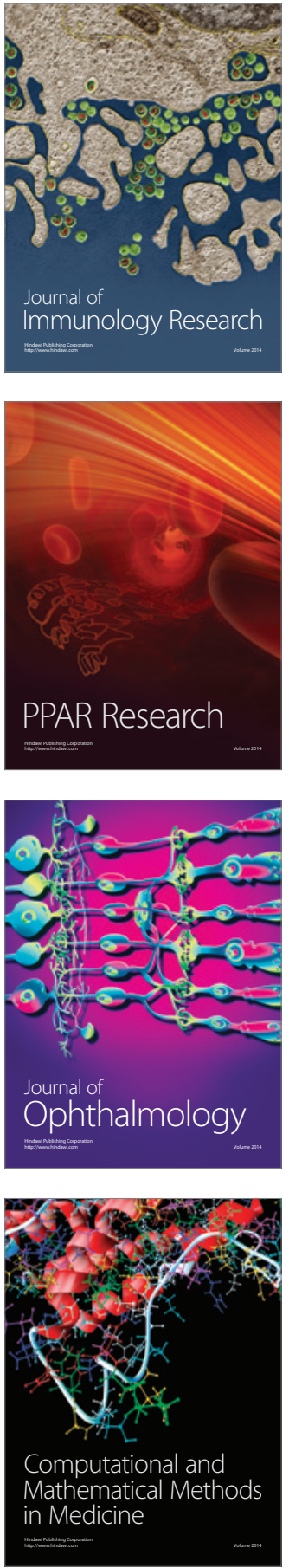

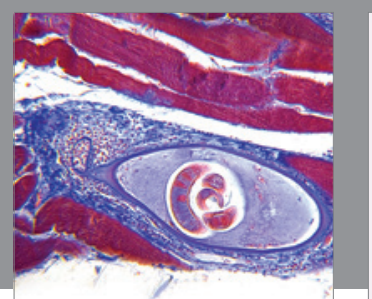

Gastroenterology Research and Practice

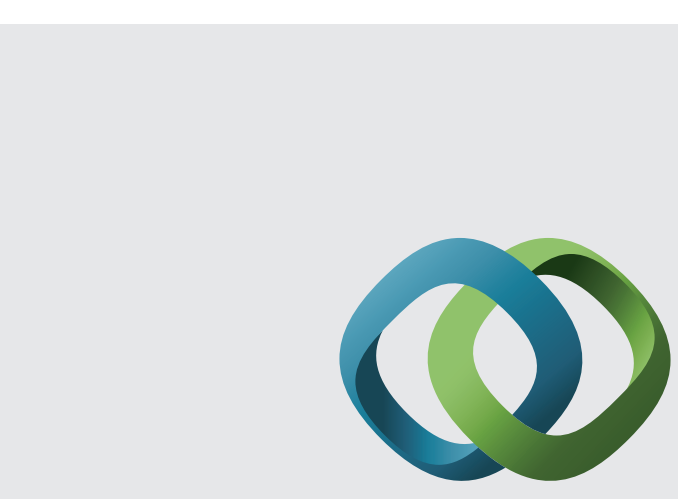

\section{Hindawi}

Submit your manuscripts at

http://www.hindawi.com
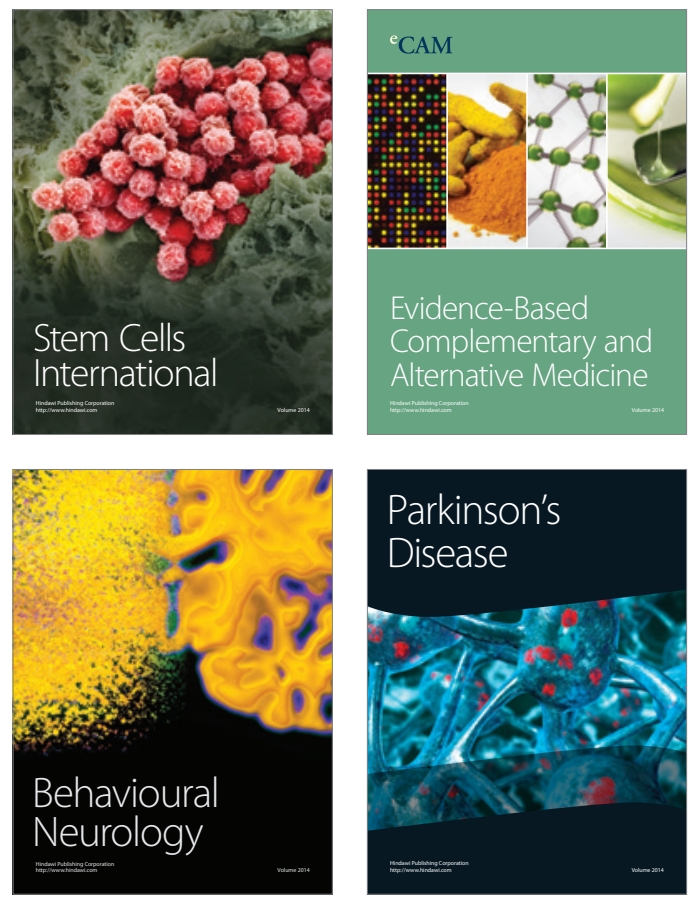
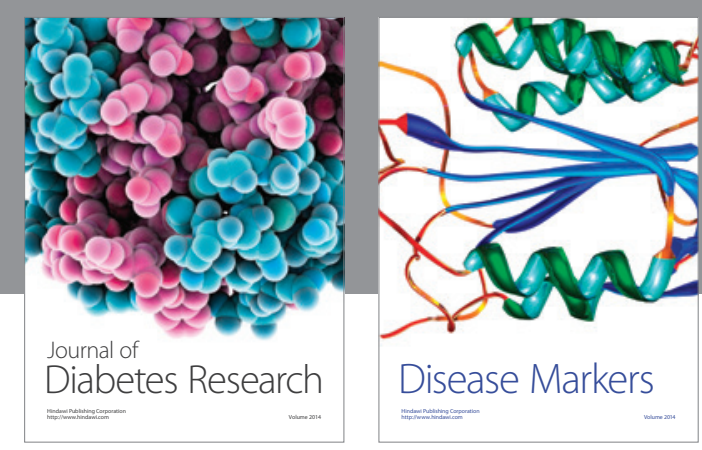

Disease Markers
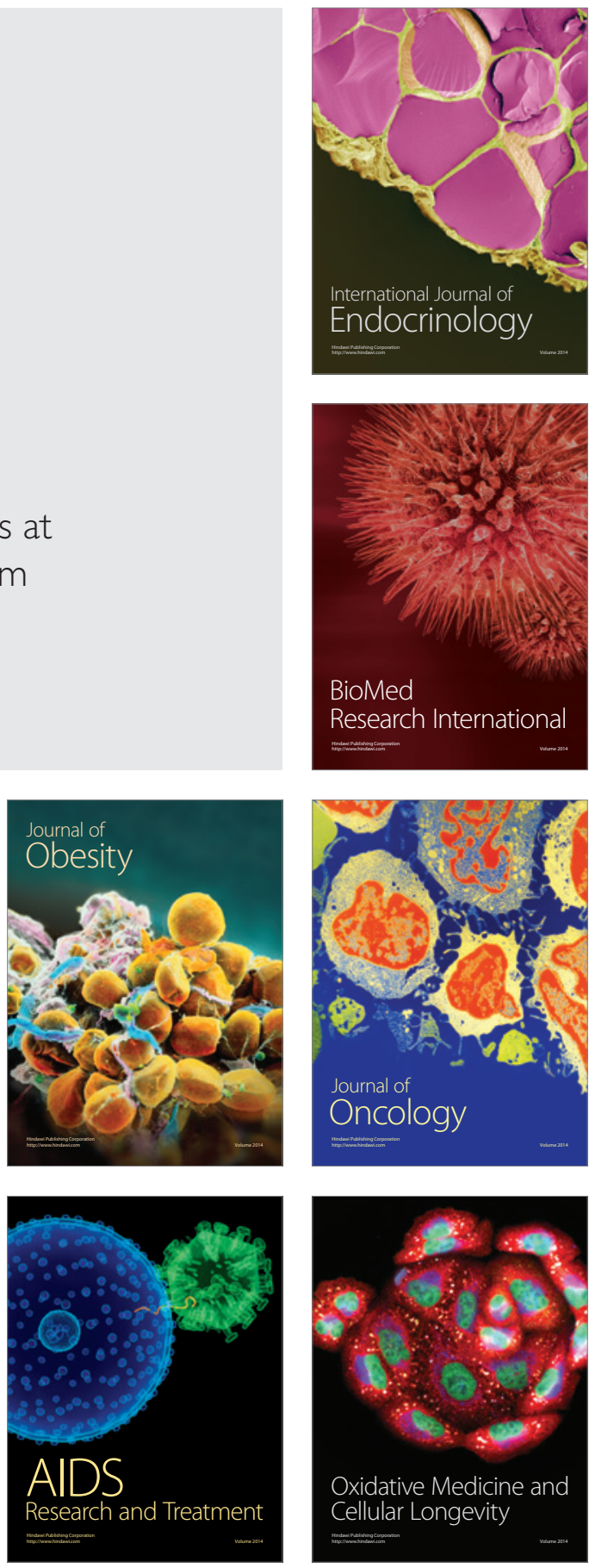